Khronika NTSh [Chronicles SNS]. (1907). Lviv. Ch. 29. S. 6. [in Ukrainian].

Zvernennia Naukovoho tovarystva im. Shevchenka pro zbyrannia dobrovilnykh pozhertvuvan na budivnytstvo u Lvovi Akademichnoho domu ta lyst upovnovazhenoho hromadskosti m. Kolomyi do Holovy NTSh pro perekazy tovarystvu zibranykh na budivnytstvo hroshei [Appeal of the Shevchenko Scientific Society on the collection of voluntary donations for the construction of the Academic House in Lviv and a letter from the public commissioner of Kolomyia to the Chairman of the SSS about the transfer of money collected for the construction of the society]. (1904) // DALO Ukrainy. F. 292. Op.1. Spr. 5. Ark. 1, 2. [in Ukrainian].

Svanyk, I. (2012). «Akademichna pomich» [«Academic assistance»]. Naukove tovarystvo imeni Shevchenka. Entsyklopediia. A. - Bibl. T. 1. S. 102-103. [in Ukrainian].

Lyst «Akademichnoi kukhni» u Lvovi do Naukovoho tovarystva im. T. Shevchenka u Lvovi z prokhanniam nadaty materialnu dopomohu [Letter of the «Academic Kitchen» in Lviv to the Shevchenko Scientific Society in Lviv with a request to provide financial assistance. Questionnaire «Academic cuisine» in Lviv]. (1914) // TsDIA Ukrainy u m. Lvovi. Anketa «Akademichnoi kukhnia» u Lvovi. F. 766. Op.1. Spr. 4. Ark. 1-4. [in Ukrainian].

Doroshenko, V. (1913). Naukove Tovarystvo imeni Shevchenka u Lvovi [Shevchenko Scientific Society in Lviv]. (1873-1892-1912). Kyiv; Lviv. S. 70-71. [in Ukrainian].

Propamiatna knyha himnazii Sester Vasyliianok u Lvovi [Commemorative book of the gymnasium of the Basilian Sisters in Lviv]. (1980). Niu-York; Paryzh; Sydnei; Toronto. S. 26-27. [in Ukrainian].

Protokoly zahalnykh zboriv [Minutes of the general meeting]. (1903-1940) // TsDIA Ukrainy u m. Lvovi. F. 309. Op. 1. Spr. 31. Ark. 48 zv.-49. [in Ukrainian].
Zvernennia do ukrainskoi hromadskosti pro nadannia materialnoi dopomohy ukrainskym studentam [Appeal to the Ukrainian public to provide material assistance to Ukrainian students]. (1921) // TsDIA Ukrainy u m. Lvovi. F. 766. Op.1. Spr. 3. Ark. 1. [in Ukrainian].

Lysty ukrainskykh studentskykh orhanizatsii «Proforus», «Sich», Spilky studentiv u Nimechchyni pro sklykannia studentskoho konhresu, peredachu prymishchen, prydbannia literatury ta in. [Letters of Ukrainian student organizations «Proforus», «Sich», the Union of Students in Germany on the convening of a student congress, the transfer of premises, the purchase of literature, etc.] (19161925) // TsDIA Ukrainy u m. Lvovi. F. 309. Op.1. Spr. 119. Ark. 13-16. [in Ukrainian].

Lysty tovarystva «Studentska samopomich» Naukovomu tovarystvu im. T. Shevchenka u Lvovi pro rozviazannia yikhnoho sporu za prymishchennia po vul. Supinskoho u Lvovi [Letters of the Society «Student Self-Help» to the Shevchenko Scientific Society in Lviv on resolving their dispute over the premises on the street Supinsky in Lviv]. (1925) // TsDIA Ukrainy u m. Lvovi. F. 399. Op.1. Spr. 163. Ark. 1, 2. [in Ukrainian].

Moroz, M. (2012). Akademichnyi dim [Academic house]. Naukove tovarystvo imeni Shevchenka. Entsyklopediia. A-Bibl. Lviv. T. 1. S. 105. [in Ukrainian].

Khronika NTSh [Chronicles SNS]. (1935). Lviv. Ch. 72. S. 23-34. [in Ukrainian].

Oholoshennia «Komitetu Akademichnoho domu u Lvovi» [Announcement of the «Committee of the Academic House in Lviv»)]. (1929-1934) // DALO Ukrainy. F. 292. Op.1. Spr. 17. Ark. 23. [in Ukrainian].

Khronika NTSh [Chronicles SNS]. (1937). Lviv. Ch. 73. S. 8-46. [in Ukrainian].

Дата надходження до редакиії: 18.05.2021 p.
УДК 373:613.9

DOI: $10.37026 / 2520-6427-2021-107-3-14-19$

\section{Іван БІЛАВИЧ,}

кандидат педагогічних наук, викладач I клініки анестезіології та інтенсивної терапї

Варшавського медичного університету, м. Варшава, Республіка Польща ORCID: 0000-0003-4561-4690

e-mail:bilawicz@wp.pl

\title{
СТАНОВЛЕННЯ І РОЗВИТОК ГІГІЕНІЧНОЇ ПРОСВІТИ ДІТЕЙ ТА ЮНАЦТВА В ЗАКЛАДАХ ОСВІТИ ГАЛИЧИНИ НАПРИКІНЦІ ХІХ - У 30-Х РОКАХ ХХ СТОЛІТЬ
}

\begin{abstract}
Анотація. Стаття присвячена гігієнічній просвіті дітей та юнацтва в Галичині наприкінщі XIX-y 30-х рp. XX cm. Крізь призму історичного досвіду висвітлено діяльність інституиій медичного спрямування (Українське гігієнічне товариство, Украӥнське лікарське товариство (УЛТ), «Медична громада», «Народна
\end{abstract}

лічниця»), освітніх, культурно-просвітницьких, жіночих, господарсько-економічних, дитячих і юнацьких, студентських, благодійнииьких, інших громадських організаиій (Украӥнське педагогічне товариство (УПТ) "Рідна школа», «Просвіта», Союз українок, "Сільський господар», "Академічна громада», Товариство 
імені Петра Могили та ін.) на ниві гігієнічного просвітництва. Проаналізовано ефективні форми, продуктивні засоби масового медичного просвітництва дітей та дорослих у Галичині, щзо істотно вилинуло на здоров'язбереження людей. На прикладі Украӥнського гігієнічного товариства (1929-1939) висвітлено те, як украӥнські громадські активісти, серед яких лікарі-«суспільники» (О. Козакевич, С. Магаляс, М. Музика, Р. Осінчук, М. Панчишин, С. Парфанович та ін.), студенти-медики, за тісної співпрачі з УЛТ, УПТ «Рідна школа», Союзом украӥнок, іншими діячами поширювали санітарно-гігієнічні знання через улаштування гігієнічних курсів, тематичних лекцій, сприяли профілактиці інфекиійних захворювань, зокрема туберкульозу, вели протитуберкульозні курси, здійснювали профілактичні огляди тощчо. Закиентовано увагу на курсовій підготовиі медичних волонтерів, дівчат-«гігієністок», наголошено на гігієнічній освіті учнів УПТ «Рідна школа», де викладали «Основи гігієни», проводили активну виховну роботу зі школярами в цьому напрямі. Проаналізовано роль українських громадських періодичних видань у поширенні гігієнічних знань дітей та юнацтва. Окреслено шляхи використання продуктивного історичного досвіду діяльності українських громадських товариств у галузі гігієнічного просвітництвва дітей та юнацтва в Галичині досліджуваного періоду за сучасних умов поширення пандемії коронавірусу.

Ключові слова: українські громадські товариства, діти, гігієнічне просвітництво, гігієна, курси, боротьба з інфекиійними захворюваннями.

Ivan BILAVYCH,

Candidate of Pedagogical Sciences,

Assistant of First Department

of Anesthesiology and Intensive Care

of Warsaw Medical University,

Warsaw, Poland

ORCID: 0000-0003-4561-4690

e-mail:bilawicz@wp.pl

\section{FORMATION AND DEVELOPMENT HYGIENIC EDUCATION OF CHILDREN AND YOUTH IN EDUCATIONAL INSTITUTIONS OF GALICIA IN THE END OF THE XIX CENTURY - IN THE 30s OF THE XX CENTURY}

\begin{abstract}
The article is devoted to the hygienic education of children and youth in Galicia in the late XIX - in the 30 s of the XX century. Through the prism of historical experience, the activities of medical institutions (Ukrainian Hygienic Society (UHS), Ukrainian Medical Society (UMS), "Medical Community», "People's Hospital»), educational, cultural, educational, women's, economic, children's and youth, student, charitable, other public organizations (Ukrainian Pedagogical Society (UPS) «Ridna Shkola», "Prosvita», Union of Ukrainian Women, «Silskyi Hospodar», "Academic Community», Petro Mohyla Society, etc.) in the field of hygienic education.

Effective forms, productive means of mass medical education of children and adults in Galicia, which significantly affected the health of people, were analyzed. On the example of the Ukrainian Hygienic Society (1929-1939) it is covered how Ukrainian public activists, especially public doctors (O. Kozakevych, S. Mahalyas, M. Muzyka, R. Osinchuk, M. Panchyshyn, S. Parfanovych and etc.), medical students, in close cooperation with UMS, UPS «Ridna Shkola», the Union of Ukrainian Women and other activists disseminated sanitary and hygienic knowledge through the organization of hygiene courses, thematic lectures, contributed to the prevention of infectious diseases, including tuberculosis,
\end{abstract}

conducted anti-tuberculosis classes, carried out preventive examinations, etc.

Emphasis was placed on the course training of medical volunteers, "hygienists» girls, as well as on the hygienic education of students of UPS «Ridna Shkola», where they taught "Fundamentals of Hygiene», conducted active educational work with students in this area. The role of Ukrainian public periodicals in the dissemination of hygienic knowledge of children and youth is analyzed. The ways of using the productive historical experience of Ukrainian public associations in the field of hygienic education of children and youth in Galicia in the study period under modern conditions of the spread of the COVID-19 pandemic are outlined.

Key words: Ukrainian public societies, children, hygienic education, hygiene, courses, fight against infectious diseases.

Постановка проблеми. За умов поширення пандемії коронавірусу, не завжди ефективних дій державних структур у боротьбі з нею, зростання смертності 3-поміж людей, ураження вірусом дітей тощо $є$ потреба в активізації громадського чинника, який би допоміг державі, медичним працівникам зупинити це інфекційне захворювання, не лише зменшити його наслідки, а й 
найголовніше - запобігти новим зараженням. Ідеться про суспільне гігієнічне просвітництво дітей, юнацтва, дорослого населення. Такий досвід за умов поширення інфекційних недуг наприкінці XIX - у 30-х pp. XX ст. мала Австро-Угорська імперія, Друга Річ Посполита та Галичина, що входила до їх складу, де зусиллями активістів, які належали до численних національних медичних (Українське гігієнічне товариство (УГТ), Українське лікарське товариство (УЛТ), «Медична громада», «Народна лічниця»), освітніх, культурно-просвітницьких, жіночих, господарсько-економічних, дитячих і юнацьких, студентських, благодійницьких, інших громадських організацій (УПТ «Рідна школа», «Просвіта», Союз українок, «Сільський господар», «Академічна громада», Товариство імені Петра Могили, КАУМ «Орли» та ін.), було створено ефективні форми, запропоновано продуктивні засоби масового медичного просвітництва дітей та юнацтва, що істотно вплинуло на здоров'язбереження українства. Цей досвід за умов творчого використання можна застосувати й сьогодні.

Аналіз наукових досліджень і публікацій. Незважаючи на те, що українські (Й. Ганіткевич (2006); I. Даценко (1995); Р. Осінчук (1975); Б. Савчук (1999); В. Трач (2017) та ін.) й зарубіжні вчені (К. Брожек (2003) та ін.) активно вивчають діяльність українських громадських товариств і медичний рух у Галичині кінця XIX - 30-х років XX століття, наукова проблема, порушена в статті, не була глибоко вивчена.

Мета статті - проаналізувати провідні тенденції розвитку українського громадського медичного просвітництва дітей та юнацтва наприкінці XIX - у 30-х роках XX ст., визначити можливості використання цього досвіду за сучасних умов поширення вірусу COVID-19 в Україні.

Виклад основного матеріалу дослідження. Наприкінці XIX століття в Галичині, що входила до складу Австро-Угорської імперії, були створені передумови для організації громадського медичного просвітництва, яке за міжвоєнного двадцятиріччя набуло окреслених організаційних форм та охоплювало гігієнічний сегмент (оздоровча реабілітація, гігієнічна освіта в навчальних закладах), рух тверезості, збереження здоров'я та фізичне виховання тощо, що постійно розвивалися та вдосконалювалися (Білавич, 2015). Важливо зазначити, що «опертя на власні сили» у розбудові суспільного медичного просвітництва демонстрували не лише українські інституції медичного спрямування, а й ті товариства, до яких належали як медики, так і студенти, педагоги, свідомі селяни, жіноцтво, діти та юнацтво, християнська молодь. До громадського руху, спрямованого на медичне просвітництво, активно долучилося все свідоме українство краю; його віковий діапазон - від учнів народних шкіл (ідеться про УПТ «Рідна школа» та інші українські приватні навчальні заклади, які були у фарватері боротьби за здоровий спосіб життя), навіть від 7-8-річних учасників пластового руху, до дорослого населення. Отже, феномен руху за здоров'язбереження полягає не лише в масовості та всеохопності різних верств населення, йому притаманна така особливість, як «омолодження», тобто діти та юнацтво надзвичайно активно та абсо- лютно добровільно, свідомо долучалися до боротьби за здоров' язбереження народу, складником якого було гігієнічне просвітництво. Найбільш популярними та поширеними в Галичині були такі форми, як художня література, періодичні видання, «виклади» і «відчити», курси, свята, тематична література, віча, «сходини» тощо, які мали практичне спрямування: пропонували необхідні практичні рекомендації щодо формування гігієнічних навичок дітей та юнацтва.

На прикладі Українського гігієнічного товариства (1929-1939) проілюструємо, як українські громадські активісти здійснювали гігієнічне просвітництво в краї. В УГТ, що за міжвоєнного десятиріччя було в епіцентрі руху за здоров'язбереження, гуртувалося чимало українського студентства (див. рис.), яке з великою самопосвятою пропагувало 3-поміж населення основи гігієнічних знань, включалося разом з іншими українськими громадськими товариствами до просвітницької діяльності, самовіддано і безкоштовно працювало в «Народній лічниці» - українській медичній установі, де надавали безкоштовно або за символічну ціну лікувально-консультативні послуги, й відповідно до статуту УГТ розбудовувало мережу лікувально-профілактичних закладів, залучало широкі верстви українців до розв'язання проблем народного здоров'я. Як представлено на рисунку, за соціальним і віковим складом УГТ можна віднести до категорії студентського товариства: станом на 1930 р. у ньому гуртувалося 117 студентів, 36 лікарів, 16 селян, 7 учителів, 7 урядовців, священник, апвокат аптекап та інженеn (О)інчук 1975 с 105-196)

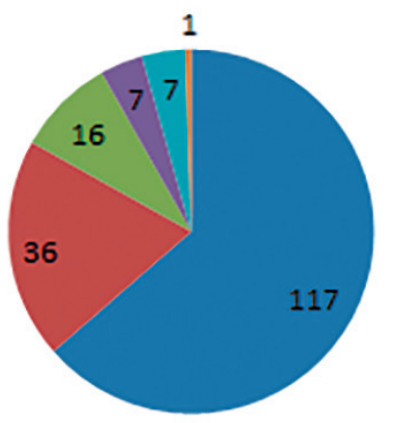

" студентів

- лікарів

селян

ш учителів

" "урядовців"

священників

\section{Рис. Соичільний склад УГТ станом на 1930 рік}

Завдяки активній діяльності медичних діячів (С. Парфанович, Т. Бурачинський, О. Козакевич, С. Магаляс, М. Музика, Р. Осінчук, П. Цимбалістий та ін.) за підтримки студентства, освітян, «поступових» сільських господарів УГТ набуло поширення в Галичині: за 9 років (1930-1939) кількість членів товариства зросла в 27 разів. Станом на 1939 р., за даними Р. Осінчука, секретаря товариства, до УГТ належало 2700 осіб (Осінчук, 1975, с. 202).

У 1930-х роках зміст діяльності УГТ означувала праця низки секцій, як-от: організаційної, видавничої, боротьби з туберкульозом, боротьби з алкоголізмом і курінням, венерологічної, євгенічної (генетичної-І.Б.), роботи з молоддю, однак пріоритетним було гігієнічне 
просвітництво дітей та юнацтва. Цій меті слугувала робота кожної з секцій, до прикладу, організаційна секція налагодила, окрім іншого, зв'язки з аналогічними медичними секціями студентських товариств у Кракові, Познані, Вільні, Польським гігієнічним товариством і Товариством боротьби з туберкульозом, єврейським Товариством охорони здоров'я у Львові, спеціалізованими видавництвами медичної періодики («Медичний архів», «Вісник Українського Червоного Хреста», «Шлях до здоров'я» з УРСР, «Вопросы туберкулёза» («Питання туберкульозу») з СРСР, «Здоровє» та «Грузліца» з Польщі) (Осінчук, 1975, с. 198-199).

Через друковане слово, тематичні видання, агітаційно-рекламні «летючки» (листівки - I. Б.), буклети, плакати тощо видавнича комісія несла в народ гігієнічні знання. У 1938 р. УЛТ і УГТ підготували до друку грунтовне видання - двотомну «Книгу здоров'я», що, по суті, була популярною енциклопедією здоров'я, матеріали до якої (понад тисяча сторінок) опрацьовував український науковець д-р М. Корнилів-Василів, однак у 1939 р. із приходом радянських військ на терени Галичини вони були знищені (Савчук, 1999, с. 67).

Дієвою була участь студентів-медиків в антитуберкульозній і антиалкогольній кампаніях 1932 і 1933 років: лише у 1928-1933 рр. вони, за нашими даними, провели близько 530 «відчитів» на зазначену тематику в усіх повітах краю. У кожному такому заході пересічно брали участь 60-90 осіб. Цей факт, а також улаштування спільно з УЛТ «протитуберкульозних» і санітарних курсів, курсів «швидкої допомоги», слухачі яких самі згодом виступали з лекціями у селах, промовисто свідчать про реальний вагомий внесок студентства у формування уявлень про гігієнічні знання 3-поміж широких верств українців (25-ліття «Народної Лічниці», 1930; 25-ліття Українського Лікарського Товариства і Медичної Громади, 1935; 3 діяльности «Медичної Громади», 1933).

Безпрецедентним освітнім явищем у розвитку гігієнічного просвітництва стало створення «гігієнічних університетів» для юнацтва та дорослого населення у вигляді навчальних курсів (різної тривалості й спрямування), які організувало УГТ за сприяння та активної підтримки УПТ «Рідна школа», «Просвіти», «Пласту», «Відродження», «Сільського господаря», Союзу українок та інших інституцій. В освітніх закладах було введено такий предмет, як гігієна, діяли учнівські осередки, педагоги проводили активну позаурочну і позашкільну виховну роботу з гігієнічного просвітництва дітей. Щорічно, починаючи з 1930 р., у грудні УГТ влаштовувало триденні протитуберкульозні курси, а шкільні лікарі та педагоги в українських навчальних закладах організовували «відчитову акцію» (лекторій - I. Б.); санітарний курс для старших пластунок у Львові (Осінчук, 1975, с. 197-199); санітарно-гігієнічні курси для членів Кружка «Рідна Школа» ім. Ганни Барвінок, товариств «Зоря», «Луг» та інших із підготовки громадських пропагандистів-лекторів. Ці курси охоплювали від 25 до 75 учасників, включали цикли лекцій із питань гігієни, поширених інфекційних захворювань, догляду за хворими, а також на них розглядали тодішні актуальні проблеми: про роль жінки в підтриманні здорового способу життя в сім’ї, гігієна жінки, гігієна сім'ї, невідкладна допомога при небезпечних для життя станах, анатомія та фізіологія людини тощо. Цю форму навчання вважаємо сміливим інноваційним рішенням того часу, адже фактично в такий спосіб здійснювали освітній коучинг: слухачі курсів, здобувши відповідні знання та сформувавши фахові навички проведення просвітницької праці, ставали вчителями-волонтерами з гігієни для інших. Громадські пропагандисти здоров'я, як дієві учасники руху за здоров'язбереження українців, «гігієністи-суспільники» вже на місцях організовували курси першої допомоги («при наглих випадках»), гігієнічні, протиалкогольні тощо (Як працюють наші дівчата, 1937), поєднували їх з іншими формами масового громадського просвітництва - виставками, святами.

Окрім консультацій у «пораднях», амбулаторії «Народної лічниці», джерелом отримання інформації під час проведення гігієнічних курсів, «підручником», «порадником» української жінки у сфері гігієни, «статевої самоосвіти» стала громадська періодика: у 1920-х рр. на сторінках «жіночих» часописів і календарів («Жіноча доля», «Жіноча воля» та ін.) уміщували публікації, з яких читачки довідувалися про особливості функціонування жіночого організму, необхідність дотримання норм особистої гігієни, правильного догляду за дитиною, уникнення фізичних ушкоджень, способи запобігання і профілактики різних захворювань у дітей і чоловіків тощо. 3 огляду на те, що українська громадська періодика була в кожній читальні «Просвіти», у кожному осередку Союзу українок, УПТ «Рідна школа» (а це практично в кожному селі краю), робимо висновок про те, що цю інформацію отримувало все свідоме галицьке жіноцтво, зважаючи на розгалужену структуру українських громадських товариств (Білавич, 2015).

Іншим важливим напрямом діяльності стала роз'яснювальна робота з профілактики захворювань та формування елементарних гігієнічних знань у дітей та юнацтва. На підставі звітів щодо діяльності УГТ за 1929-1931 рр. можемо стверджувати про певні успіхи в цій ділянці: члени товариства підготували близько 80 тематичних рефератів, виступили із понад 300 лекціями, провели десятки триденних лекторіїв. Число учасників цих просвітніх заходів вражає - близько 40-50 тисяч селян. Українські медики та студенти поширили тисячі примірників «рефератів» (бромур, листівок - I. Б.) і «таблиць» (агітаційних плакатів - I. Б.), які в доступній формі знайомили дітей та дорослих із симптомами захворювань, правилами надання допомоги хворим, а також заходами із запобігання виникнення і поширення недуг. Цікаво, що таку профілактично-роз'яснювальну діяльність громадські діячі проводили й на Волині, Холмщині, Поліссі (Звіт з діяльності, 1930; Звіт з діяльності, 1931).

У травні 1929 р. УГТ завдяки зусиллям знаного лікаря і науковця, громадського діяча М. Панчишина спільно 3 «Народною лічницею» заснувало у Львові перший у Польщі український протитуберкульозний диспансер, який поставив за мету оглянути галичан задля раннього виявлення хворих на туберкульоз, а отже, лікування їх та профілактику цієї недуги (Даценко, 1995). Поширення туберкульозу в краї мало загрозливі 
для генофонду українства характер і темпи (Куровець, 1919). Учений ініціював наукове дослідження, спрямоване на боротьбу з туберкульозом, на початковому етапі якого (збір інформації про стан захворювання на «сухоти» методом анкетування під час «гігієнічних відчитів» по селах, через спілкування з місцевим населенням, сільською управою) з'ясували стан санітарно-епідеміологічної ситуації; лише за перший рік проведення анкетування було опрацьовано інформацію про 50 населених пунктів із різних повітів (від Закарпаття до Полісся) (Осінчук, 1996, с. 205). У зв'язку з ліквідацією «гігієнічної неграмотності» населення виникла потреба активізації просвітницько-консультативної діяльності членів секції боротьби з туберкульозом: із цією метою придбали 35 рентгенограм із різних форм туберкульозу органів людського та тваринного організмів, 34 макети із профілактики та епідеміології, 36 томів наукової літератури, того ж 1929 р. улаштували десятки лекцій, які відвідало близько 13000 слухачів (Білавич, 2015; Звіт 3 діяльності Українського гігієнічного т-ва у Львові, 1930; Звіт з діяльності Українського гігієнічного т-ва у Львові, 1931; 3 діяльности «Медичної громади, 1933).

Сьогодні є нагальна потреба в підготовці медичних працівників до організації медичної опіки населення за умов пандемії, випрацювання нових освітніх програм для підготовки медиків-волонтерів, суспільних медичних працівників. Рух за здоров'язбереження санітарно-гігієнічне просвітництво - має об'єднати все свідоме населення. Пропагандистами-волонтерами та учасниками цього руху можуть бути не тільки медичні працівники, студенти медичних закладів, а й учні шкіл, студенти закладів вищої освіти, учителі, викладачі, громадські активісти, свідомі сільські мешканці, священники. Цього вчить продуктивний досвід минулого. 3-поміж основних засобів, методів та форм діяльності в цьому напрямі сьогодні актуалізуємо такі: «гігієнічні університети» для населення, особливо сільського, що спрямують роботу на поширення знань і популяризацію матеріалів про здоров'язбереження за умов пандемії COVID-19 (зокрема і через інтернет та інші соціальні мережі); лекційну пропаганду гігієни та гігієнічних знань; консультування людей щодо запобігання поширенню хворобі, спричиненої вірусом COVID-19; видання інформаційних листків («летючок», агіток, календарів, буклетів тощо) та тематичної науково-популярної літератури; організація масової соціальної гігієнічної реклами; улаштування санітарно-гігієнічних курсів для населення та «протиковідних» курсів, курсів «швидкої допомоги» для медиків-волонтерів, зокрема із числа студентів, які згодом улаштовуватимуть таке навчання серед населення; введення до змісту освіти в школах курсу «Основи гігієни»; створення тематичних літературних творів гігієнічної тематики; організацію оздоровлювальних таборів для дітей, юнацтва, які перенесли COVID-19, у Карпатах; створення «порадень» для матерів щодо здоров'язбереження, профілактики захворювань дітей; забезпечення кожного закладу середньої освіти лікарем тощо.

Висновки. Отже, рушійною силою гігієнічного просвітництва в Галичині наприкінці XIX - у 30-х pp. XX ст. виступили медичні та громадські діячі, освітяни, студенти, свідоме селянство, активістки жіночого руху, згуртовані в УГТ, «Народній лічниці», УЛТ, «Медичній громаді», товаристві «Відродження», інших інституціях. Вони спрямували свої сили на розгортання боротьби 3 інфекційними захворюваннями, зокрема туберкульозом, розвиток консультативної діяльності. Навколо проблеми здоров' язбереження українців відбулося зближення медичного й освітнього руху, активізація праці лікарів-«суспільників» та студентів-медиків, а організовані УГТ спільно з УЛТ протитуберкульозні й санітарні курси, курси «швидкої допомоги», літні мандрівні школи тощо стали важливими формами масового гігієнічного просвітництва; дієвим засобом у поширенні гігієнічних знань виступила також українська фахова й громадська періодика, художня література.

Потреба подальшого поглибленого дослідження порушеної проблеми зумовлена низкою суперечностей між: потребою налагодження масового гігієнічного просвітництва і пропаганди гігієнічних знань із-поміж дітей та юнацтва за умов поширення пандемії коронавірусу й малоефективною діяльністю у цьому напрямі педагогів, медичних і соціальних працівників, церковнослужителів, особливо в сільській місцевості; декларуванням у базових державних освітніх і соціальних документах пріоритетів збереження і охорони здоров'я громадян України, зокрема й завдяки формуванню здоров'язбережувальних компетентностей тощо, та відсутністю комплексної науково обгрунтованої освітньо-педагогічної концепції, яка б окреслила теоретичні аспекти цієї проблеми та практичні механізми їі розв'язання; нагромадженням значного світового і національного досвіду функціонування системи медичної опіки дітей і юнацтва та недостатнім його вивченням і застосуванням у процесі сучасного реформування медичної та освітньої галузей України, зокрема у формуванні з-поміж українства уявлень, знань, переконань про необхідність дотримуватися здорового способу життя.

\section{СПИСОК ВИКОРИСТАНОЇ ЛІТЕРАТУРИ}

Ганіткевич, Я. (2006). Українська медицина Львова до початку Другої світової війни. НTШ. URL: http:// ntsh.org/content/ukrayinska-medicina-lvovado-pochatkudrugoyi-svitovoyi-viyni (дата звернення: 10.06.2021).

Даценко, I. (1995). Професор Маркіян Панчишин засновник Українського гігієнічного товариства у Львові. Acta Medica Leopolensia. № 1. Ч. 2-3. С. 11-12.

Осінчук, Р. (1975). На стийці народного здоров'я. Українське гігієнічне товариство у Львові. Матеріали до історії української медицини. Нью-Йорк; Мюнхен: Українське Лікарське Товариство Північної Америки. T. 1. C. 191-224.

Савчук, Б. (1999) Просвітницька та соціально-економічна діяльність українських громадських товариств у Галичині (остання третина XIX ст. - кінець 30 -х років XX ст.). Івано-Франківськ: Плай. 138 с.

Трач, В. (2017). Гігієнічні часописи та формування дискурсу громадського здоров'я у Львові на початку ХХ століття. Місто: історія, культура, суспільство. № 2 (4). C. 136-161.

Brożek, K. (2003). Ruch na rzecz podnoszenia kwalifikacji zawodowych polskich lekarzy w latach 18051952. Towarzystwa i kursy. Medycyna Nowożytna. № 10 
(1-2). S. 35-98.

25-ліття «Народної Лічниці». (1930). Львів. 14 с.

25-ліття Українського Лікарського Товариства i Медичної Громади. (1935). Львів. 129 с.

3 діяльности «Медичної Громади». (1933). Сmyдентський шлях. № 10-12. С. 324-325.

Білавич, I. (2015). Внесок українських лікарів у розвитку вітчизняної науки та медичної опіки дітей та дорослих (кінець XIX - початок XX ст.). Людинознавчі студіï. Педагогіка. № 31. С. 25-33.

Звіт 3 діяльності українського гігієнічного товариства у Львові за час від 21.01.1929 до 28.11.1930. (1930). Львів. 12 с.

Звіт з діяльності Українського гігієнічного товариства у Львові за рік 1930/31. (1931). Львів. 8 с.

Куровець, I. (1919). Житє і здоровлє людий. Біольогічно-гігієнічна розвідка. Львів: Друкарня Наукового Товариства ім. Шевченка. 65 с.

Як працюють наші дівчата. Помічниця у лікаря. (1936). Світ молоді. № 4 (1). С. 7-8.

\section{REFERENCES}

Hanitkevych, Ya. (2006). Ukrainska medytsyna Lvova do pochatku Druhoi svitovoi viiny. NTSh [Ukrainian medicine in Lviv before the Second World War]. URL: http:// ntsh.org/content/ukrayinska-medicina-lvovado-pochatku-drugoyi-svitovoyi-viyni (data zvernennya: 10.06.2021). [in Ukrainian].

Datsenko, I. (1995). Profesor Markian Panchyshyn - zasnovnyk Ukrainskoho hihiienichnoho tovarystva u Lvovi [Professor Markiyan Panchyshyn is the founder of the Ukrainian Hygienic Society in Lviv]. Acta Medica Leopolensia. № 1 (2-3). S. 11-12. [in Ukrainian].

Osinchuk, R. (1975). Na stiitsi narodnoho zdorovia. Ukrainske Hihiienichne Tovarystvo u Lvovi [At the public health stand. Ukrainian Hygienic Society in Lviv]. Materiialy do istorii ukrainskoi medytsyny. Niu-York; Miunkhen: Ukrainske Likarske Tovarystvo Pivnichnoi Ameryky. № 1. S. 191-224. (In Ukrainian). [in Ukrainian].

Savchuk, B. (1999) Prosvitnytska ta sotsialno-ekonomichna diialnist ukrainskykh hromadskykh tovarystv u Halychyni (ostannia tretyna XIX st. - kinets 30-kh rokiv XX st.) [Educational and socio-economic activity of Ukrainian public societies in Galicia (the last third of the XIX century - the end of the 30 s of the XX century)].
Ivano-Frankivsk: Plai. 138 s. [in Ukrainian].

Trach, V. (2017). Hihiienichni chasopysy ta formuvannia dyskursu hromadskoho zdorovia u Lvovi na pochatku XX stolittia [Hygienic periodicals and the shaping of discourse of public health in Lviv at the beginning of the XXth century]. Misto: istoriia, kultura, suspilstvo. № 2 (4). S. 136-161. [in Ukrainian].

Brożek, K. (2003). Ruch na rzecz podnoszenia kwalifikacji zawodowych polskich lekarzy w latach 1805-1952. Towarzystwa i kursy [Movement for the improvement of professional qualifications Polish doctors in the years 1805-1952. Societies and courses]. Medycyna Nowożytna. № 10 (1-2). S. 35-98. [in Poland].

25-littia «Narodnoi Lichnytsi» [25th anniversary of the «Narodnoi Lichnytsi»]. (1930). Lviv. 14 s. [in Ukrainian].

25-littia Ukrainskoho Likarskoho Tovarystva i Medychnoi Hromady [25th anniversary of the Ukrainian Medical Society and Medical Community]. (1935). Lviv. 129 s. [in Ukrainian].

Z diialnosty «Medychnoi Hromady» [From the activities of the Medical Community]. (1933). Studentskyi shliakh. № 10-12. S. 324-325. [in Ukrainian].

Bilavych, I. (2015). Vnesok ukrainskykh likariv u rozvytok vitchyznianoi nauky ta medychnoi opiky ditei i doroslykh (kinets XIX - pochatok XX st.) [Contribution of Ukrainian doctors to development of native science and medical guardianship of children and adults (late XIXth early XXth century)]. Liudynoznavchi studii. Pedahohika. № 31. S. 25-33. [in Ukrainian].

Zvit z diialnosty Ukrainskoho hihiienichnoho tovarystva u Lvovi za chas vid 21.01.1929 do 28.11.1930 rr. [Report on the activities of the Ukrainian Hygienic Society in Lviv for the period from January 21, 1929 to November 28, 1930]. (1930). Lviv. 12 s. [in Ukrainian].

Zvit z diialnosty Ukrainskoho hihiienichnoho tovarystva u Lvovi za rik 1930/31 [Report on the activities of the Ukrainian Hygienic TV in Lviv for the year 1930/31]. (1931). Lviv. 8 s. [in Ukrainian].

Kurovets, I. (1919). Zhytie i zdorovlie liudyi. Biologichno-higiienichna rozvidka [Life and health of people. Biological and hygienic work]. Lviv: Drukarnia Naukovoho Tovarystva im. Shevchenka. 65 s. [in Ukrainian].

Iak pratsiuiut nashi divchata. Pomichnytsia u likarky [How our girls work. Assistant to doctors]. (1936). Svit molodi. № 4 (1). S. 7-8. [in Ukrainian].

Дата надходження до редакиіï: 05.08.2021 p. 


\section{УПРАВЛІННЯ ОСВІТОЮ. ПРОФІЛЬНЕ НАВЧАННЯ}

УДК 373.5:37.091

DOI: 10.37026/2520-6427-2021-107-3-20-25

\author{
Оксана ВІРОЛАЙНЕН, \\ аспірантка кафедри педагогіки, \\ адміністрування та соиіальної роботи \\ Навчально-наукового інституту \\ менеджменту та психології \\ ДЗВО «Університет менеджменту освіти», \\ заступник директора із навчально-виховної роботи \\ комунального закладу освіти \\ «Середня загальноосвітня школа № 58» \\ Дніпровської міської ради, \\ м. Дніпро, Украӥна \\ ORCID: 0000-0001-5959-434X \\ e-mail:vera.77.147@gmail.com
}

\section{ОСОБЛИВОСТІ УПРАВЛІНСЬКОЇ ДІЯЛЬНОСТІ В УМОВАХ УПРОВАДЖЕННЯ ТЕХНОЛОГІЙ ЗМІШАНОГО НАВЧАННЯ В ЗАКЛАДІ ЗАГАЛЬНОЇ СЕРЕДНЬОЇ ОСВІТИ}

\begin{abstract}
Анотація. Із метою організації високоефективного освітнього процесу в умовах упровадження змішаного навчання в закладі загальної середньої освіти необхідно вивчати та враховувати особливості управлінської діяльності. Низка вчених України та світових дослідників вивчали організачійно-педагогічні основи управління закладом освіти, проте під впливом глобальних освітніх змін суспільство вимагає нового погляду на означену проблему. Завдяки сучасним технологіям, котрі використовуються в закладі освіти, управлінський аспект набуває новітніх та інноваційних відтінків системи організачії освітньої діяльності. Прочес навчання може відбуватися будь-де та у будь-який час, єдина умова - підключення до мережі «Інтернет». Така форма навчання надає змогу впровадженню інтерактивних технологій викладання освітнього матеріалу. У статті
\end{abstract}

виокремлено й проаналізовано управлінські функиії та задачі, необхідні для організації інновачійного освітнього процесу, скерованого вимогами часу. Завдяки вивченню иього матеріалу визначено завдання $i$ зміст управлінської діяльності успішного керівника закладу освіти щодо розвитку професійної компетентності вчителя. Зроблено висновок, який визначає рівень системності в закладі загальної середньої освіти, а також вказує на створення ефективної функиіонуючої системи, щуо відповідає міжнародним стандартам.

Ключові слова: дистаниійна освіта, змішане навчання, інформаційні технології, управління закладом загальної середньої освіти, освітній проиес, система управління, впровадження інтерактивних технологій викладання, функиії управління, модель керівника закладу загальної середньої освіти.

\author{
Oksana VIROLAINEN, \\ Graduate student of the Department of Pedagogy, \\ Administration and Social work SIHE \\ "University of Education Management», \\ Deputy Director for Educational \\ Work Communal Institution \\ «Secondary school № 58» Dnieper City Council, \\ Dnieper, Ukraine \\ ORCID: 0000-0001-5959-434X \\ e-mail:vera.77.147@gmail.com
}

\section{FEATURES OF MANAGEMENT ACTIVITY IN THE CONDITIONS OF INTRODUCTION OF MIXED LEARNING TECHNOLOGIES IN GENERAL SECONDARY EDUCATION}

\footnotetext{
Abstract. It has been determined that it is necessary to study and take into account the peculiarities of management activities in order to organize a highly effective educational
}

process in the introduction of blended learning in general secondary education. Number of Ukrainian scientists and world researchers have studied the organizational 